\title{
Explaining Design Dimensions of Ecological Greenways
}

\author{
Mohammadreza Pourjafar, Amir Moradi* \\ Department of Urban and Regional Planning, Faculty of Art and Architecture, Tarbiat Modares University, \\ Tehran, Iran \\ Email: amir.moradi@modares.ac.ir
}

Received 12 February 2015; accepted 6 March 2015; published 11 March 2015

Copyright (C) 2015 by authors and Scientific Research Publishing Inc.

This work is licensed under the Creative Commons Attribution International License (CC BY). http://creativecommons.org/licenses/by/4.0/

(c) $\underset{\mathrm{EY}}{\mathrm{B}}$ Open Access

\begin{abstract}
Design of greenways is one of the most important planning tools in the promotion of quality of life of the city residents. Greenways are necessary due to their major role in increase of air quality and positive changes in the climate of the urban environments for keeping the environmental quality of the cities and considerably increasing aesthetic values of these environments. Protection of natural ecological systems, provision of extensive recreational opportunities for people in urban regions and rural districts, provision of economic benefits and protection of cultural values and historical heritage are the advantages of designing and creating greenways inside cities. The present paper which was conducted with descriptive-analytical method tried to explain design dimensions of ecological greenways in three urban physical, environmental and social-economic systems by studying suitable experimental concepts and samples in the world. In this regard, this paper studied five main goals of designing greenways: promotion of local and urban accesses with greenways, aesthetic aspects of urban landscapes, improvement of performance and distribution of activities by creating greenways, increase of efficiency and environmental aspects in the city and revival of social values considering economic sustainability and in this regard design strategies and policies were presented for each one of them based on these goals.
\end{abstract}

\section{Keywords}

Greenway, Urban Design, Design Strategies and Policies

\section{Introduction}

Natural environments inside cities have been limited to separated parks and green spaces along the passages or

*Corresponding author. 
have been left from the natural structures of the urban buildings. Lack of connection of these spaces with each other and nature of the city gradually reduces quality of urban space and finally instability of natural and manmade spaces. Connection of the urban environments to each other and with the surrounding nature of the city like the historical and valuable monuments leads to protection of natural monuments and structures.

Creation of greenways and environmental ways inside the city started since 19th half-century in America. The initial goals of creation of these ways are protection of land and natural environments inside cities and promotion of urban life quality. These ways have been also used for urban transportation, recreation and communication with nature [1] [2].

To create continuity between the natural and historical structures in cities, different strategies have been presented during history such as the parkways which have been built to create urban recreational ways in 19th half-century in Paris and the park systems which have been initiated by Frederick Olmsted and Boston Park System to create communication between urban parks and places of urban recreational activities since the late 19th century [1] or the greenbelt was created by Ebenezer Howard in 1898 to prevent excessive development and growth of cities [3]. One of these strategies is use of ecological green axes, which has multiple environmental, historical and cultural and recreational goals in addition to creation of continuity between natural and historical structures and protection of them and leads to stability of natural and historical structures.

On this basis, this paper has been written to answer this question: what are the most important principles and strategies of urban design for design of greenways inside city? In this regard, hypothesis of this paper is that if we explain the urban collection with three physical, environmental and social-economic systems, presentation of goals, strategies and policies of urban design can be defined for design of greenways in these three systems. The research method in the present paper is descriptive-analytical based on library data. In this regard, goals, strategies and policies of designing urban greenways have been extracted and presented by reviewing theoretical fundamentals and studying successful global experiences. Diagram 1 shows the research process.

\section{Concept of Greenways}

William White, the distinguished writer of environment, first innovated the term "greenway" and applied it in his thesis entitled "provision of open space for American city" which was published by Academy of Urban Land in 1959 [4] [5].

In this regard, different definitions of this word have been created in scientific texts of the world and some of them are mentioned as follows:

Viles \& Rosier believe that riverside buffers in cities which are the main elements of forming the cities are the best samples of urban greenways and they have discussed them. They have rich environmental and aesthetic values like rivers and cultural corridors and play effective role in control of urban development as the border of city. They mention effects of greenways from environmental viewpoints in two fields:

- Renovation and improvement of communication in landscape;

- Protecting ecological [6].

Griffin has evaluated effects of greenways on three social, economic and human aspects. From the social viewpoint, promotion of the quality of life is one of the main goals and effects of greenways. This increases enjoyment of beauty, recreational opportunities, mental and social interaction between people and nature. From the economic viewpoint, it can be said that one of the most important economic effects resulting from greenways is reinforcement and expansion of tourism. With increasing price of the properties adjacent to greenways, not only the owners and local residents but also government takes advantage of tax. From the human viewpoint, greenways are effective on humans and users by reducing pollutions and increasing cleanness level, expanding nature to access borders, visual and urban beauties, physical and personal security after attendance and interaction of different social groups in urban fields [7].

Little defined greenway as linear open spaces along natural or artificial reliefs of the land including useless railways, roads, rivers and channels [5]. He also describes linear parks, open spaces and protected zones in cities, suburbs and the surrounding countryside as way and he describes greenway as follows:

1) Walking and bicycle tracks which are combined with landscaping and green space.

2) It acts as linear park in local scale.

3) It has been formed along a natural corridor linearly, for example, river, and valley or along the routes with recreational use. 
4) An open communication space [5].

Fabos defines the greenways as the corridors which have been connected to each other with different width in a system similar to highways and railways networks [8].

In addition, European Greenways Association mentions formation of an interconnected network of accesses by connecting to each other and with other recreational ways such as bicycling, horse-riding, walking, skating tracks [9].

Ahren defines the greenway: greenway is a network comprising of linear elements which have been planned, designed and managed for multiple ecological, recreational, cultural, aesthetic goals or other purposes with land use idea [10]. Specifications and goals of greenways from the viewpoint of Ahern shown in Table 1.

Turner mentions that greenways are defined as linear spaces including planned, designed and managed elements with multiple ecological, recreational, cultural, aesthetic purposes [11]. Turner writes in the book "City as Landscape" in 1998: It is not compulsory for the greenways to have green space and the special passageways in which shops have been built can be regarded as greenway if they are environmental pleasant while they are not green space. This way should be a safe way for movement of the pedestrian from a point to another point [12]. It can be said that urban corridors have recreational, social and environmental functions [13].

Among them, the defection which has been expanded with idea of greenways network has more chance in the world. This idea has been connected to each other for making open and green spaces sustainable, adjacent green spots as linear corridors [14] and create ecological network. Although idea of connection is very important in greenways [15], different functions such as Bicycling, skating, walking [16] and environmental protection [17] have been allocated to ecological greenways.

Today, they are also regarded as recreational places in addition to walking, bicycling ways and motorways. Considering the mentioned definitions, it can be stated that these definitions mention role of greenway in three urban physical, environmental and socioeconomic systems which are detailed in Table 2.

\section{History of Greenways}

History of the greenways can be divided into five periods which are given as follows:

First period is emergence of the first generation of the greenways as axes, boulevards and parkways in 1700 . These ways have been derived from axes of ceremonies and formalities of the Rome in the middle Ages which connected seven yards of the church to each other as pilgrimage ways and performance of these axes, displacement, experience of successive view and connection of the separate yards. Elegant boulevards such as Élysée in Paris who connected urban spaces to each other were created. Such ways aimed to manifest beauty and express power. Haussmann created a main axis in Paris for communication of separated yards and creation of control and displaying grandeur and connected other access ways to this axis. Frederick Law Olmsted inspired by European boulevards created parkways and park systems with approach of beautiful landscape which was an introduction to concept of greenway [18].

Second period: the most important greenway project was conducted by Olmsted.

In USA as Boston Park System in 1876 to 1900 [1]. After Olmsted, his pupils expanded his attitudes by creating park systems and greenway network with attitude toward movement of beautiful city. In addition to Olmsted and his pupils, other landscape architect also planned important greenways in this period in America.

Table 1. Specifications and goals of greenways from the viewpoint of Ahern, 1995 [10].

Goals of forming a greenway

1) Giving priority to nature

2) Promotion of walking

3) Promotion of environment

4) Providing facilities to people

5) Protecting and strengthening natural and recreational charismas

6) Preventing and reducing soil destruction trend

7) Improving condition of rivers and floodways

8) Developing recreational opportunities
Specifications of a greenway
1) Environmental corridor
2) Recreational function or close interaction with nature
3) With historical and cultural value 
Table 2. Studying concept and strategies of design of greenways from the viewpoints of theorists.

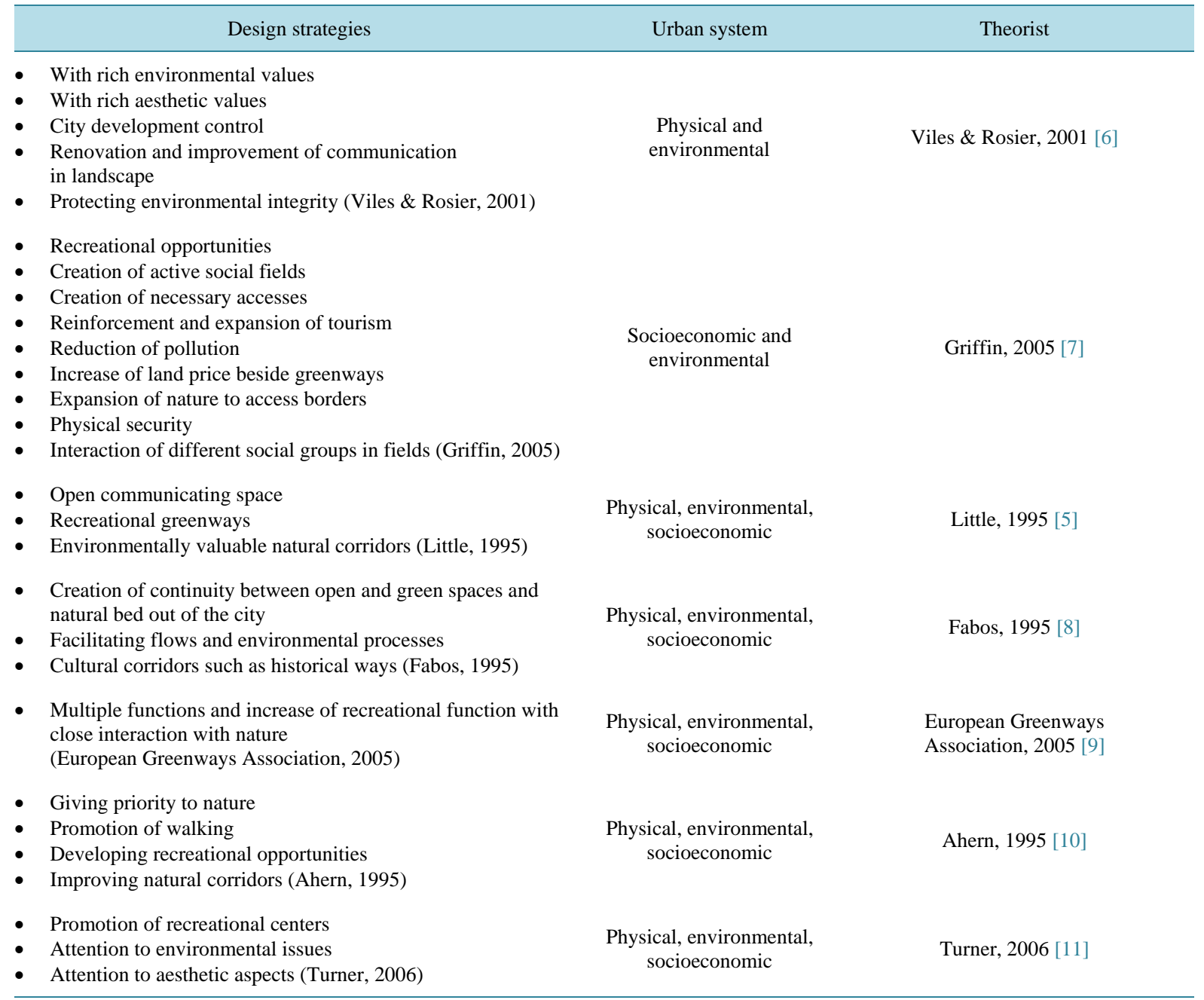

Other landscape architects also planned important greenways in this period in America.

Third period starts since 1900. Planning and design of urban parks and national parks continued in century 20 and a new concept of open space planning was innovated in this period [19]. At the same time (early century 20), greenways were planned in Europe. It started in Germany and in Schmidt's paper on spatial planning which had been published since 1912. Considering growing trend of globalization of European communities particularly Germany, he emphasized on creation of green spaces network to separate habitats, recreational regions to improve air cleanness in early years of century 20 [17]. Then, the greenways were formed in England with activity of the planners who were affected by Olmsted in America and the works conducted in Germany between 1900 and 1947 [11].

Fourth period starts since the second half of century 20 when the second generation of greenways was created in reaction to industrialization of cities. One of the important projects of this period was conducted by Philip Lewis in 1960 to 1970 . He identified 220 natural and cultural resources in Wisconsin State and converted it into plan. He found that all of them were connected to each other through different corridors particularly rivers which was called environmental corridors. In this period, one can name Ian MacHarg due to his very impressive book entitled "Design with Nature" [1]. In this period, sustainable development movement starts. Shortage of open spaces and increase of need for urban recreation diverted attentions to greenways in 1980. By starting environmental movement in early 1980, concept of greenway as urban landscape removed challenges in environment and landscape [18]. In this period, greenways planning was considered and used in Asia and particularly eastern and southeastern countries such as China, Japan and Singapore [20]. The first strategic plan was con- 
ducted for development of Singapore in 1971 and then in Malaysia and the used strategies were as follows: open spaces and parks should be designed and planned as a part of a network to make use of the limited resources. Large parks and open spaces should be connected to each other with the green corridors which have at least width of $20 \mathrm{~m}$ [14].

Fifth period started since 1980 up to now in which greenway mission was expanded to protect natural habitats and vulnerable ecosystems, protect cultural resources and protect against flood of river, control erosion and instruct and interpret nature in addition to fulfillment of recreational needs and long-term economic advantages became a strong reason for execution of greenway plans in the world. 80s was named greenway movement. Charles Little published a book in 1990 by reviewing 16 greenway projects. In 1998, European Greenways Association was founded in Belgium and laws of this association aimed to promote, create and improve greenways and encourage people to use it. In 1991, London green strategy created a hierarchy of green networks which overlapped with each other in some ways and included walking track, bicycle track and axes of nature [11] and these movements continued up to now.

Considering the five-period classification of this movement and writing of its change trend, it can be said that 3 generations are specified in evolutionary trend of greenways:

Urban axes and boulevards;

Urban recreational ways or in the natural environments out of city;

Multipurpose greenways which are present in urban environments and natural environments out of cities.

On this basis, the most important movements and activities of this period are explained in Table 3 based on the presented periods:

\section{Advantage and Function of Greenways}

One of the most important goals of greenways in city is promotion of urban environment quality in different scales. In regional scale, these ways prevent segmentation process and lead to stability of biological communities and increase of biodiversity against extinction [21].

In addition, it prevents natural disasters such as flood and erosion and leads to increase of air quality and leads to more communication of people with nature by connecting open and green spaces to public spaces and centers in cities and districts and allows recreational activities beside the environmental goals. Urban greenways fulfill daily needs of people for communication with nature and are of the major sources of beauty in urban environments because they are regarded as places for taking rest, stop and focus by creating natural scenes and comfortable and pleasant environments and also provide informal and social visits as the public spaces on the other hand. In addition, nearness to nature leads to more familiarity with it and is indirectly effective in education and promotion of public culture and use of nature and protection of it.

In addition, greenways socially allow interaction between humans on the one hand by creating necessary accesses and social active fields and facilitate interaction between humans and environments by expanding green spaces in urban privacy. In modern societies which long-term lifestyle with work and without recreation causes

Table 3. Studying historical dimensions and evolutionary trend of concept of ecological greenway.

\begin{tabular}{|c|c|c|c|}
\hline Period and year & Known movements & $\begin{array}{l}\text { The most important } \\
\text { conducted activities }\end{array}$ & $\begin{array}{c}\text { Classification of urban system } \\
\text { of the activities }\end{array}$ \\
\hline $\begin{array}{c}\text { First period } \\
\text { (1700 to } 1850 \text { A.D.) }\end{array}$ & $\begin{array}{l}\text { Bulldozer urban } \\
\text { development } \\
\text { park building }\end{array}$ & $\begin{array}{l}\text { Élysée boulevards of Paris } \\
\text { religious ways of Rome } \\
\text { American parkways }\end{array}$ & Physical, environmental, social \\
\hline $\begin{array}{c}\text { Second period } \\
\text { (1850 to } 1900 \text { A.D.) }\end{array}$ & Beautiful city & Boston park system & Physical, environmental, \\
\hline $\begin{array}{c}\text { Third period } \\
\text { (1900 to } 1950 \text { A.D.) }\end{array}$ & Open space planning & $\begin{array}{c}\text { Green space network in Germany } \\
\text { Greenways of England }\end{array}$ & Environmental \\
\hline $\begin{array}{c}\text { Fourth period } \\
\text { (1950 to } 1980 \text { A.D.) }\end{array}$ & Environmental movement & $\begin{array}{l}\text { Wisconsin ecological network } \\
\text { Design with nature } \\
\text { Greenway projects in Singapore and } \\
\text { Malaysia }\end{array}$ & Physical, environmental, \\
\hline $\begin{array}{c}\text { Fifth period } \\
(1980 \text { up to now })\end{array}$ & $\begin{array}{c}\text { Greenway } \\
\text { sustainable development }\end{array}$ & $\begin{array}{c}\text { European Greenways Association } \\
\text { London greenm strategy } \\
\text { global activities of greenway }\end{array}$ & Physical, environmental, social \\
\hline
\end{tabular}


depression and inefficiency of the person in all of his/her life aspects and it is possible to travel in short time of the year, diversity in behavior, place and climate of the living place causes happiness in life of the person. The presence of urban greenways which pass through the main centers of the city whether during leisure time or during dealing with routine affairs reduces mental distresses of the people and leads the people to confrontation and social sound interactions. Advantages of greenways are given in Table 4.

\section{Types of Greenways}

Fabos classifies greenways in to three classes based on their constituent resources:

1) The greenways which act as natural systems and corridors in ecological index and such greenways lack recreational access and act only as protective corridors.

2) The recreational greenways which are beside water along with the ways for walking beside landscapes and natural beautiful scenes.

3) Greenways with historical and cultural heritages which are protected as historical and cultural heritages in addition to recreational accesses [8].

In terms of performance, they can be classified into recreational, environmental, protective, cultural and historical types [22]. Charles Little in book "Greenways of America” (1990) has classified greenways into 5 classes:

1) Urban river greenways: as part of the redevelopment plan for the forgotten or destroyed coastal edges and river of the cities

2) Recreational greenways: long ways which have been built based on nature are created on tunnels, the deserted ways of the railways and public transportation ways.

3) Valuable environmental natural corridors: they are usually along the rivers and have been seldom bordered and are used for immigration of wildlife and movement of species, study of nature and walking.

4) Historical beautiful ways: they are usually created along roads, highways or waterways and in the places which are only for the pedestrian's access and access of the vehicles has been limited.

5) Comprehensive greenways system and networks have been formed based on shape of land such as valleys and reliefs [5].

At the end, Viles \& Rosier classify all types of greenways based on the researches as follows: recreational greenways, landscape greenways, ecological greenways, historical and cultural greenways, ecological greenways, river greenways, urban border greenways and greenways networks [6].

Considering the mentioned classifications of greenways, the writer believes that combined greenways have the highest function in urban field. In these greenways, some performances with equal importance are found. For example, the greenway which has all historical, recreational, social and environmental aspects has the highest performance among the greenways.

Table 4. Advantages of ecological greenways based on different attitudes, source: the writers, based on (Viles \& Rosier, 2001) [6].

\begin{tabular}{|c|c|c|}
\hline Attitudes & Advantages & $\begin{array}{l}\text { Urban system } \\
\text { intervention }\end{array}$ \\
\hline Landscape ecology & $\begin{array}{l}\text { Potential of greenways to reduce negative effects caused by discontinuity } \\
\text { due to continuity and integration in landscape. } \\
\text { Creation of synergy in the landscape by connecting cultural and ecological } \\
\text { resources to a network or system. } \\
\text { Potential of greenways to create legibility and transparency in structure of } \\
\text { landscape and reinforcement of sense of place. }\end{array}$ & Physical, environmental \\
\hline Agricultural & $\begin{array}{l}\text { Preventing soil erosion and formation of runoffs, reinforcement of } \\
\text { food cycle, reduction of wind speed, creation of shade and shelter } \\
\text { for animals, creation of moisture in air and soil etc. }\end{array}$ & Environmental \\
\hline Social & $\begin{array}{l}\text { Having educational aspects relating to nature, creation of } \\
\text { transportation tracks in which energy is not consumed. }\end{array}$ & Socioeconomic \\
\hline Economic & $\begin{array}{l}\text { Increasing value added, expanding truism and creating } \\
\text { job and commercial opportunities. }\end{array}$ & Socioeconomic \\
\hline Managerial & $\begin{array}{l}\text { As greenbelt: limitation of development, reduction of } \\
\text { pollution and promotion of landscape beauty. }\end{array}$ & Physical, environmental \\
\hline
\end{tabular}




\section{Studying Global Experiences in the Field of Greenways}

\subsection{Champs-Elysées Axis Related to Paris Saint River}

In Ile de la Cité, Paris was founded in 360 A.D. As shown in Figure 1, the primary fence of Paris City was natural fence of the river. Then, the next fences were created. Axis developments were founded since century 16 by establishing rural gardens out of the city and the primary core of linear growth of known Champs-Elysées axis started by constructing complex of palace and Tuileries Garden (Figure 2) since that time [23].

By creating important elements along the Champs-Elysées axis during Louis XV, this axis was considered as the most important element of spatial design of 1860 A.D. by establishing Paris. Actions of Haussmann for reconstruction of Paris during Napoleon I between 1850 led to huge and direct boulevards which connected the important squares and buildings to each other.

Change in nature of Tuileries Garden design from static to dynamic state was made with an axis which starts with the garden and continued along Tuileries street or Champs-Elysées street to Place de la Concorde. In evolutionary trend of the Champs-Elysées historical axis toward west of Seine River, as shown in Figure 3, a new center called La Défense was created for Paris City.

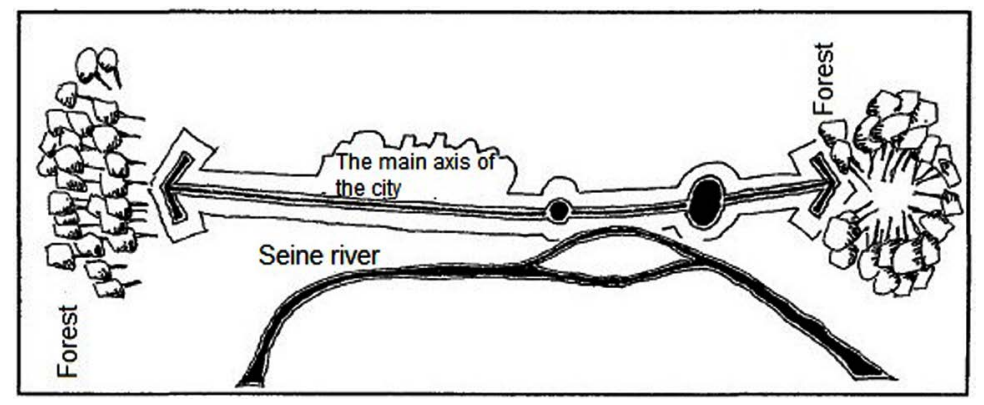

Figure 1. Primary structure of Paris City [24].

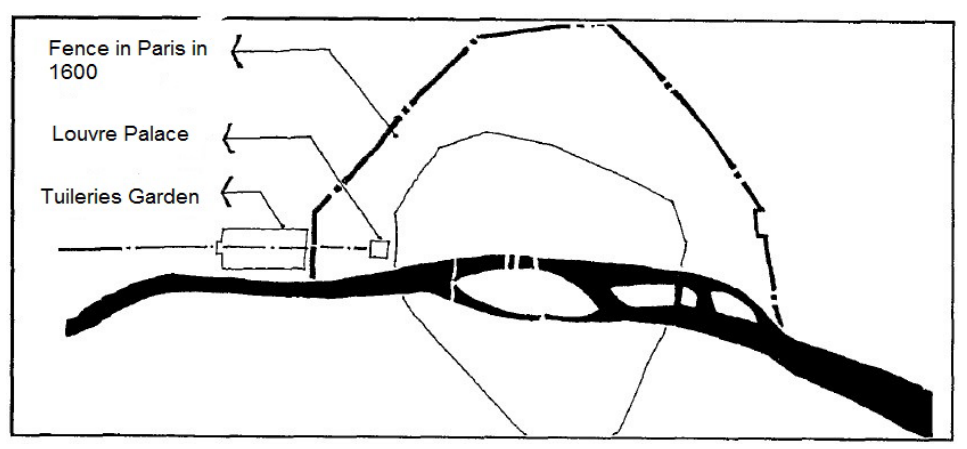

Figure 2. Location of Louvre Palace and Tuileries Garden relative to the old fence of Paris City in century 16, Garden [24].

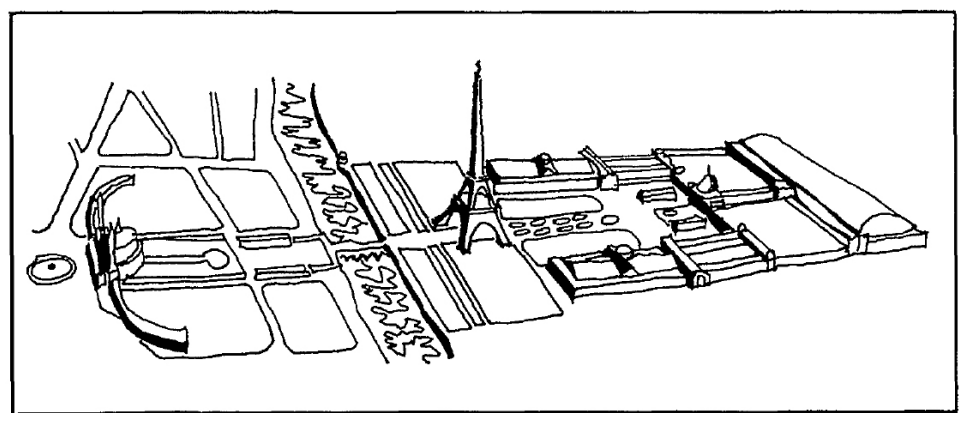

Figure 3. Location of distinguished elements along Champs-Elysées axis beside Seine River [24]. 
In addition to Seine River as natural element and column of the city, Champs-Elysées axis is located in skeleton of the city as an artificial axis which shows historical trend of the city expansion with distinguished elements such as Bastille Castle, Tuileries Palace, Louvre museum, royal palace collection, Eglise de la Madeleine, Paris Opera, Eiffel Tower, Cathédrale Notre Dame de Paris, Triumphal arch, United States Capitol, Boadu Bologna and finally La Défense collection in center of the present Paris City (Figure 4). Durability of Paris and its beauty are based on the motor axis and this is the main motion of city which passes through Seine River and forms the next developments of Paris.

Champs-Elysées axis has considered passage of time and history of the city with order of the buildings belonging to different historical periods and visual continuity and different historical sections of the city are revived and included in its symbolic network with suitable combination of the urban signs. The presence of river caused formation of important axes and buildings in parallel or diagonally or vertically to it [24].

\subsection{Taj Historical Corridor, Conjunction of History and Culture beside Yamuna River}

Private place of tombs garden and palaces of the kings and nobles is located on both sides of the river beside Yamuna Riverin centuries 16 and 17. The landscapes and movement routes among the gardens had been designed carefully for creation of continual and tangible experience of the river. In 1994, USA Park International Center proposed Taj international park project for eastern coast of Yamuna River which started from Taj Mahal and encompassed residues of Mahtab Garden and some villages in eastern coats. As you can see in Figure 5 and Figure 6, since 2003, Central state started executing their project for historical Taj Mahal Corridor as lands recovery project in the riverside between Taj Mahal and AgraFort for commercial and recreational complex purposes. Despite many disagreements, this project successfully gave the residents and tourists access to the riverside and created a greenbelt around Taj [25].

The traditional Charbagh with its square design was made toward the river instead of being parallel to the river. To enjoy the breeze and new landscape of river, these gardens were terraced toward the river. To have access to water, deep wells were drilled and the Qanat was directed to basins and channels on the ground with conventional methods. Another important factor which created unique landscapes beside the river was monuments and tombs which had been built with marble and sandstone along the riverside strip. In terms of visual communication, the most successful example was the view axis which connected Taj Mahal and Mahtab Garden. These two gardens had formed a large Charbagh collection on two sides of the river at the center of which there was Taj Mahal and among which river passed [26].

Entrance of the garden was a gate which was located at the beginning of the axis ending to the monument or palace in the middle or at the end of the garden (Figure 7). Terraces located at riverside made vertical move-

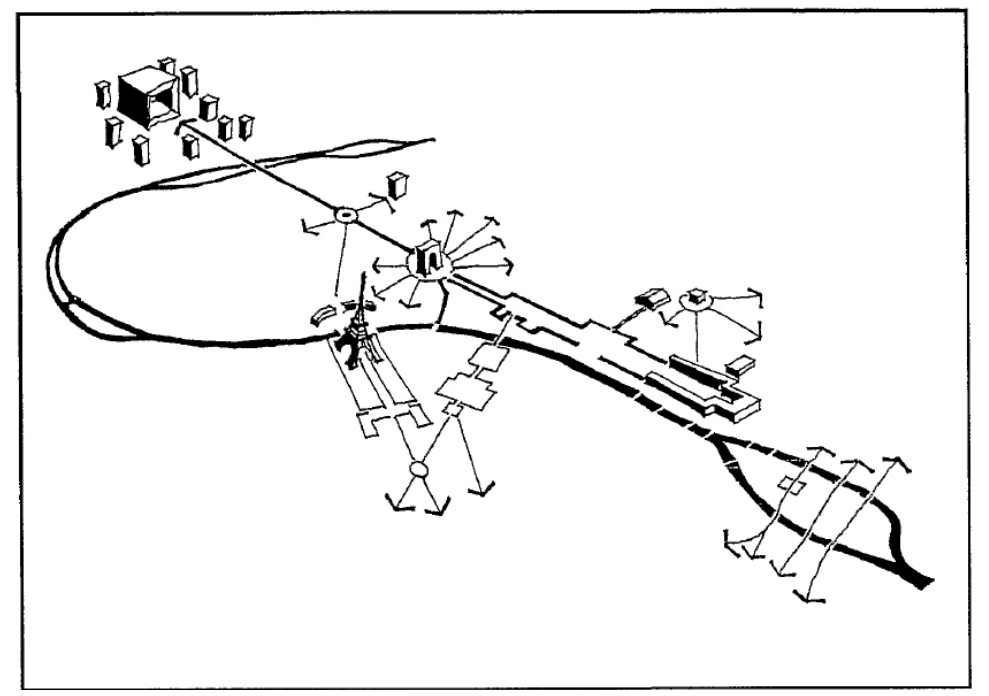

Figure 4. Location of distinguished elements along Champs-Elysées axis beside Seine River [24]. 


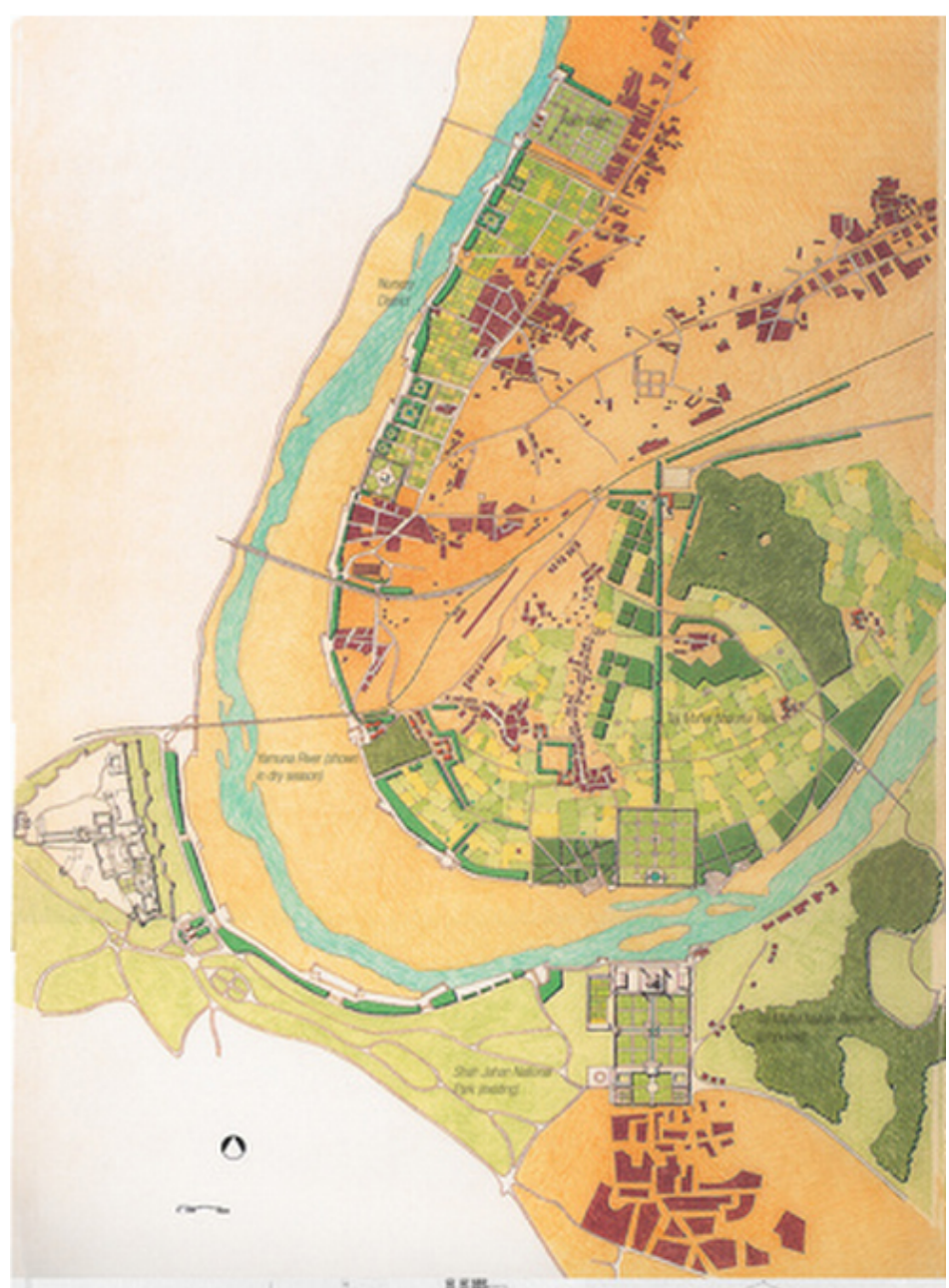

Figure 5. Detailed plan of Charbagh axis vertical to the river with interrelated networks of open spaces and parks [25].

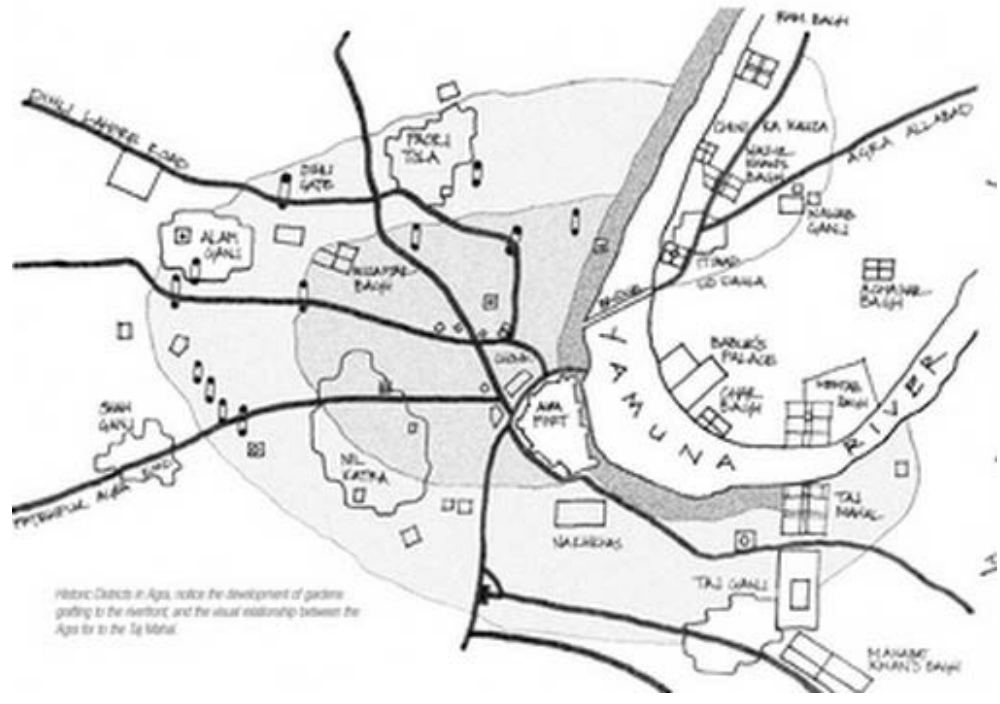

Figure 6. Detailed plan of Charbagh axis vertical to the river with interrelated networks of open spaces and parks [25]. 
ment of the garden from edge of the river possible. The terraced monuments with the protruded balconies not only increased view scope to the river but also created view to evident signs such as Taj Mahal. The riverside gardens were designed under aesthetic concepts of Iranian courts and the river was regarded as a sacred landscape as well as the public asset [27].

While protection of historical sites is of special importance, the visual experience of the visitors of the entire historical rich bed is regarded as priority of the projects by creating view corridors and having access to these places. The resorts which connect components of the historical site to each other and makes the riverside landscape enter urban domain are of the main components of this project. In Taj project, the walking route will be the main axis for walking inside the site which guarantees legal and executive protection and also public access. This zone not only includes historical site in riverside but also includes green spaces between and around them. The walking route along the river allowed the visitors to have tangible experience of the historical site in the river by connecting to the access systems of the city. This corridor shows framework of landscape in centuries 16 and 17 A.D. which creates dynamic view in different sequences of the tombs and monuments of the palaces. This movement route connects open space system in the complex including walking routes, squares, gardens and parks. The initial project includes creation of walking routes toward Taj among the mango trees and greenways and perfect development includes the Charbagh route scenario which is located in west of Mahtab Garden and a secondary garden in east of Mahtab Garden (Figure 8). The visitors move along the river through a shaded resort and experience the historical site and ecological axis [25].

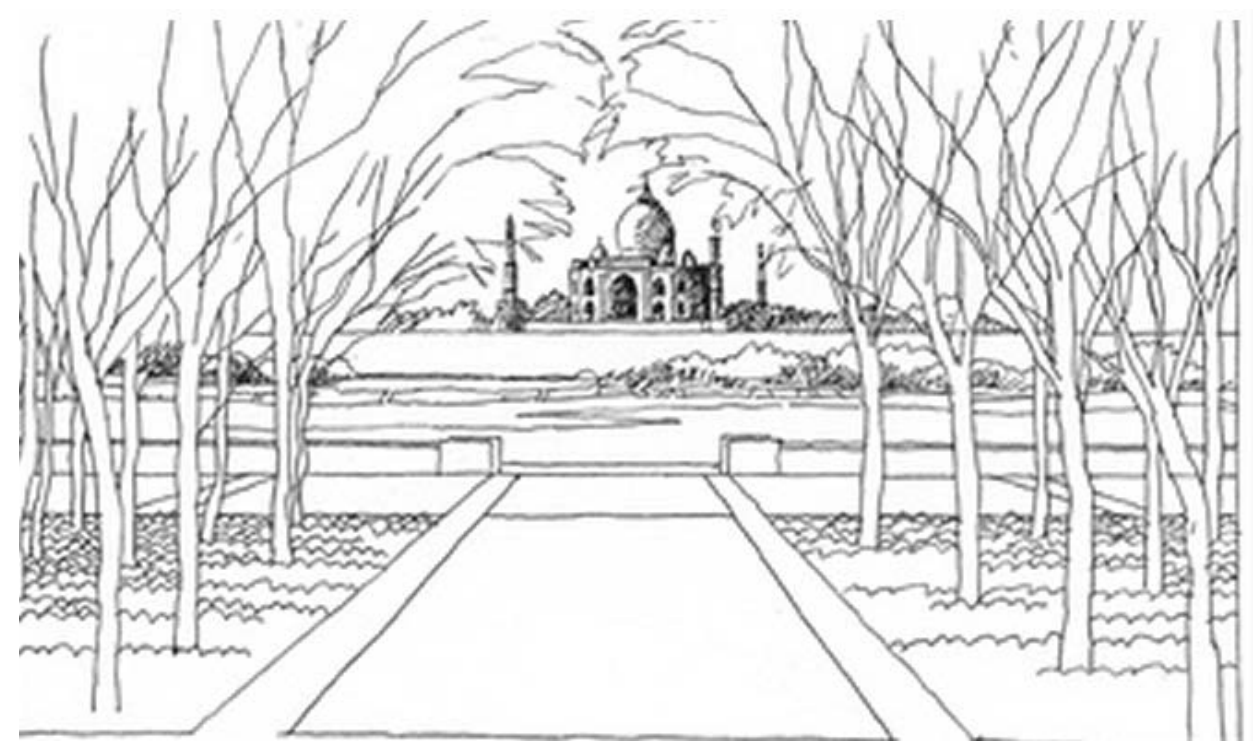

Figure 7. Taj Mahal [25].

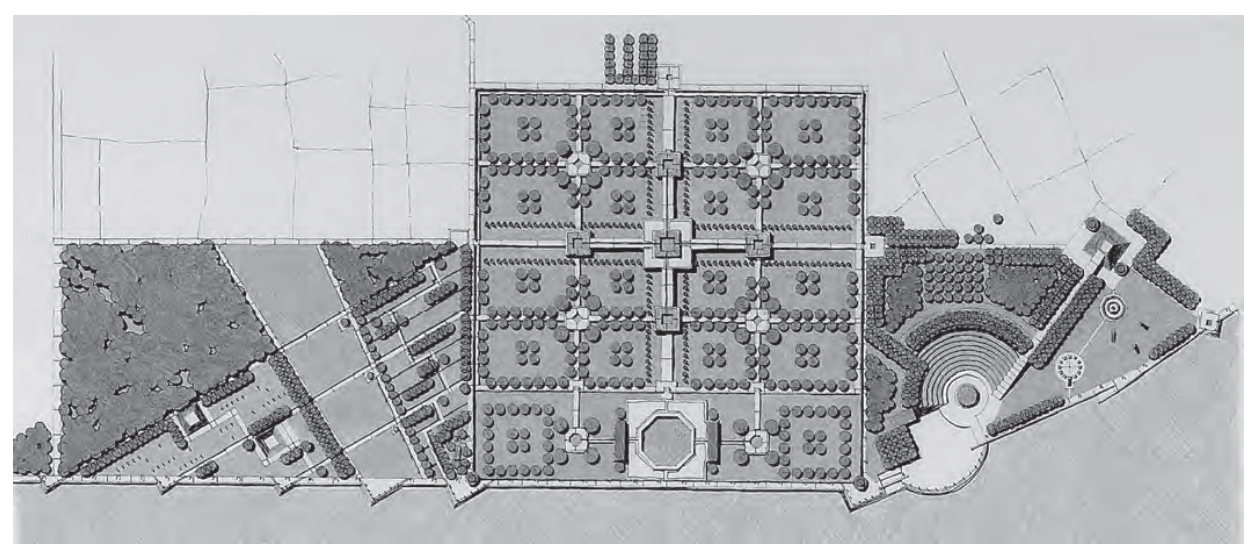

Figure 8. Design of greenway along Yamuna River [25]. 


\subsection{Extraction of Design Strategies from Successful Global Samples}

According to the explanations provided about the samples, design strategies obtained from these samples are shown in Table 5.

Table 5. Extraction of design strategies of the successful global samples.

\begin{tabular}{|c|c|c|c|}
\hline $\begin{array}{l}\text { Experimental } \\
\text { sample }\end{array}$ & Specifications of the sample & Design strategies & $\begin{array}{l}\text { Urban system } \\
\text { intervention }\end{array}$ \\
\hline $\begin{array}{l}\text { Taj Mahal } \\
\text { Corridor, India }\end{array}$ & $\begin{array}{l}\text { - The presence of historical and distinguished } \\
\text { artificial elements in the site } \\
\text { - The presence of permanent river } \\
\text { - Movement among gardens and corner of river } \\
\text { - Design of Charbagh axis vertically to the river } \\
\text { or interrelated networks of open spaces and } \\
\text { parks } \\
\text { - Visual communication between two } \\
\text { elements on two sides of the river }\end{array}$ & $\begin{array}{l}\text { - Creation of view and access corridors } \\
\text { - Creation of visual } \\
\text { - communication of the } \\
\text { elements around the river } \\
\text { - Use of class design for access to the } \\
\text { best ventilation and airflow } \\
\text { - Design of motion route with open } \\
\text { space system in the complex which } \\
\text { includes walking routes, squares, } \\
\text { gardens and parks. }\end{array}$ & $\begin{array}{c}\text { Physical, } \\
\text { environmental, } \\
\text { social, economic }\end{array}$ \\
\hline $\begin{array}{l}\text { Champs-Elysées } \\
\text { axis, Paris }\end{array}$ & $\begin{array}{l}\text { - Visual continuity } \\
\text { - The presence of historical and distinguished } \\
\text { artificial elements in the site } \\
\text { - The presence of permanent river } \\
\text { - Showing order of the buildings belonging to } \\
\text { - } \text { different historical periods on the way } \\
\text { - Suitable combination of urban signs }\end{array}$ & $\begin{array}{l}\text { - Attention to collective memories and } \\
\text { signs of the studied zones } \\
\text { - Use of site potentials to create visual } \\
\text { and functional continuity } \\
\text { - Design based on principles of space } \\
\text { dynamicity and liveliness of space }\end{array}$ & $\begin{array}{c}\text { Physical, } \\
\text { environmental, } \\
\text { social, economic }\end{array}$ \\
\hline
\end{tabular}

\section{Extraction of Design Goals}

As mentioned in the previous stages, all design goals and strategies of the greenways can be explained in three physical, environmental and social systems.

On this basis and considering the mentioned materials, it can be mentioned that the main goals include promotion of local and urban accesses with greenways, increase of aesthetic aspects of urban landscape and improvement of performance and distribution of activities by creating greenways which are located under the physical system. Increase of efficiency and environmental aspects in the city which are defined in environmental system and revival of the social values considering economic sustainability which is defined in socioeconomic system and based on these goals, design strategies and policies based on urban systems are given in Table 6 .

Table 6. Urban design policies and strategies for greenways design.

\begin{tabular}{|c|c|c|c|c|}
\hline Systems & Goals & Strategies & Policies & Conceptual image \\
\hline $\begin{array}{l}\text { Physical } \\
\text { system }\end{array}$ & $\begin{array}{l}\bullet \\
\text { Promotion of } \\
\text { local and } \\
\text { urban } \\
\text { accesses with } \\
\text { greenways }\end{array}$ & $\begin{array}{l}\text { - } \quad \text { Connecting } \\
\text { important centers } \\
\text { to promotion of } \\
\text { walking } \\
\text { - Increased } \\
\text { permeability to } \\
\text { greenways due to } \\
\text { the legibility and } \\
\text { integrity } \\
\text { Expanding the } \\
\text { nature to } \\
\text { boundaries } \\
\text { of access }\end{array}$ & $\begin{array}{l}\text { - Hybrid design for connecting between existing } \\
\text { residential and commercial spaces and } \\
\text { compliance with the greenways designed } \\
\text { - } \quad \begin{array}{l}\text { Definition of restricted access to private } \\
\text { vehicles }\end{array} \\
\text { - Define greenway for busesto displacement of } \\
\text { people } \\
\text { - Given the requirement for access to all parts of } \\
\text { greenway for } \\
\text { vehicles such as fire, ambulance and police car } \\
\text { - Creating appropriate joints in design for } \\
\text { connecting between the various spaces and } \\
\text { define way in enters of greenways. } \\
\text { Prevent the advance of urban elements in the } \\
\text { range of green spots by the greenways }\end{array}$ & 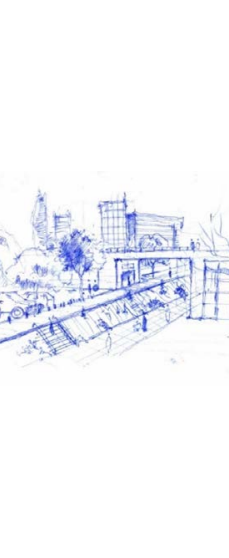 \\
\hline
\end{tabular}




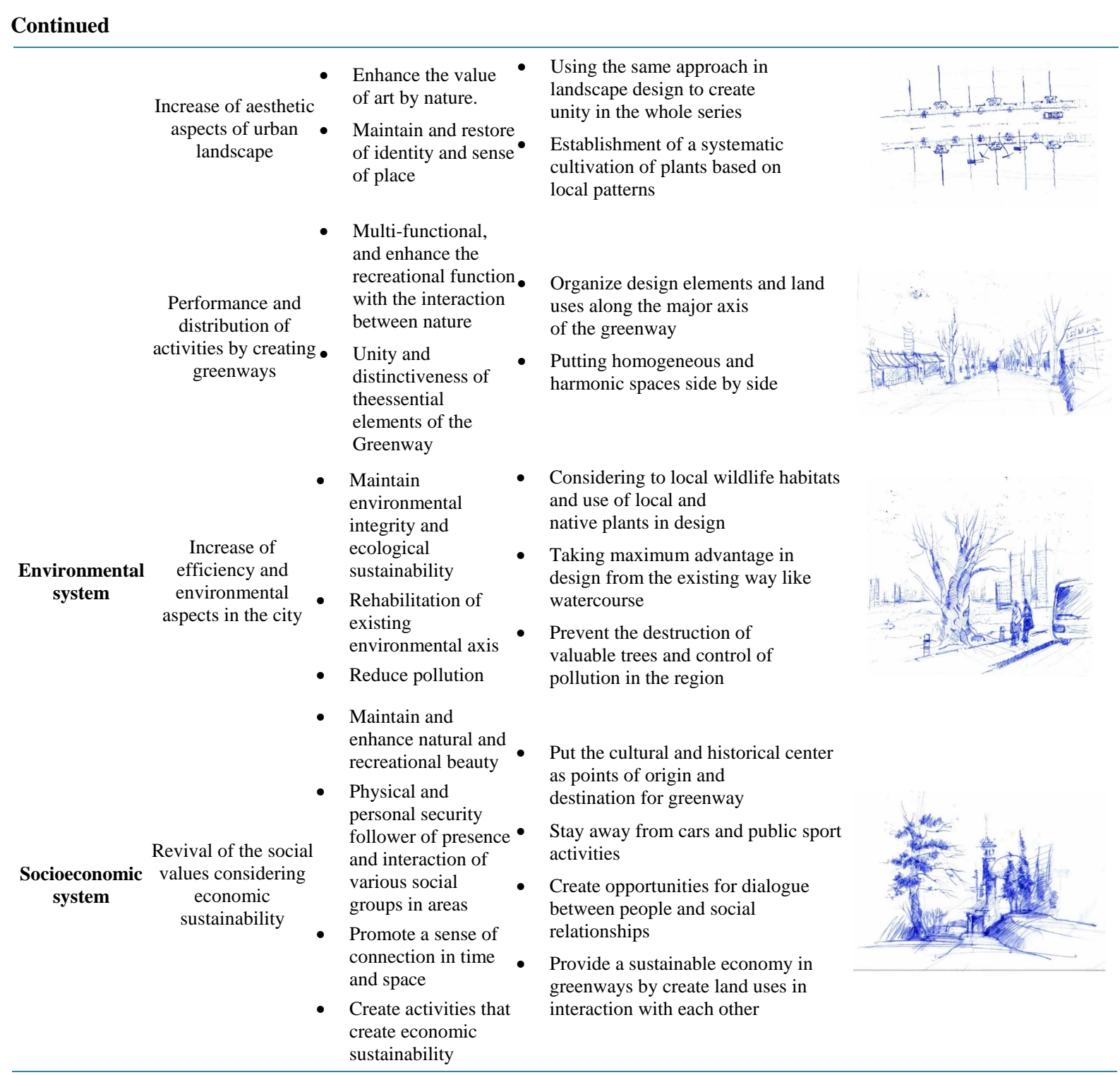

\section{Conclusion}

Results of this research show that in case greenway or greenways can be designed considering urban equipment and ground for a city, these ways can be effective in ecological quality of the city and also visual quality and aesthetic aspects of the environment and as a result, they can increase or decrease feeling of environments attachment and landscape care among the citizens. These ways also can promote quality of life of the citizens from economic, educational, cultural, recreational, environmental, health and security viewpoints. As a result, as mentioned in the design policies, expansion of using the greenways particularly as the greenway networks in cities could be effective in increase of citizens' satisfaction and many other cases which were mentioned before. This case can have a positive effect on feeling of environments attachment among the citizens and their responsibility feeling for protection and care of natural and ecological capitals. Results of this research show that it will be necessary to institutionalization use of greenways as a useful and applied tool for expansion of greenway in cities and environmentally sustainable development. For this purpose, the components related designs can be also prepared by showing the status quo of each city relating to these ways, determining landscape, goals and ideals while presenting strategic plan of greenways for that region. Functions of the greenways include broad scope of benefits and contributions in social, economic, cultural, agricultural, urban management, biodiversity 
and leisure time fields. In this regard, characteristic of the native and ecofriendly plants and their use will play a determining role in creation and promotion of native and environmental identity of each city.

\section{References}

[1] Fábos, J.G. and Ryan, R.L. (2004) International Greenway Planning: An Introduction. Landscape and Urban Planning, 68, 143-146. http://dx.doi.org/10.1016/S0169-2046(03)00155-5

[2] Zhao, X.G. and Pan, Y. (2013) Greenway: Origin, Planning Features and Significance. Applied Mechanics and Materials, 295, 2660-2664. http://dx.doi.org/10.4028/www.scientific.net/AMM.295-298.2660

[3] Ignatieva, M., Stewart, G.H. and Meurk, C. (2011) Planning and Design of Ecological Networks in Urban Areas. Landscape and Ecological Engineering, 7, 17-25. http://dx.doi.org/10.1007/s11355-010-0143-y

[4] Fabos, J.G. and Ahern, J.F. (1996) Greenways: The Beginning of an International Movement. Elsevier Amsterdam, The Netherlands.

[5] Little, C.E. (1995) Greenways for America. JHU Press, Baltimore.

[6] Viles, R. and Rosier, D. (2001) How to Use Roads in the Creation of Greenways: Case Studies in Three New Zealand Landscapes. Landscape and Urban Planning, 55, 15-27. http://dx.doi.org/10.1016/S0169-2046(00)00144-4

[7] Griffin, S.T. (2005) Study of Methods for Greenways Acquisition in City Planning. Texas A\&M University, College Station.

[8] Fabos, J.G. (1995) Introduction and Overview: The Greenway Movement, Uses and Potentials of Greenways. Landscape and Urban Planning, 33, 1-13. http://dx.doi.org/10.1016/0169-2046(95)02035-R

[9] European Greenways Association (2005) European Greenways Good Practice Guide: Examples of Actions Undertaken in Cities and the Periphery. European Greenways Association.

[10] Ahern, J. (1995) Greenways as a Planning Strategy. Landscape and Urban Planning, 33, 131-155. http://dx.doi.org/10.1016/0169-2046(95)02039-V

[11] Turner, T. (2006) Greenway Planning in Britain: Recent Work and Future Plans. Landscape and Urban Planning, 76, 240-251. http://dx.doi.org/10.1016/j.landurbplan.2004.09.035

[12] Turner, T. (2014) City as Landscape: A Post Post-Modern View of Design and Planning. Taylor \& Francis, UK.

[13] Baris, M., Erdogan, E., Dilaver, Z. and Arslan, M. (2010) Greenways and the Urban Form: City of Ankara, Turkey. Biotechnology \& Biotechnological Equipment, 24, 1664-1657. http://dx.doi.org/10.2478/V10133-010-0022-6

[14] Tan, K.W. (2006) A Greenway Network for Singapore. Landscape and Urban Planning, 76, 45-66. http://dx.doi.org/10.1016/j.landurbplan.2004.09.040

[15] Zhang, L. and Wang, H. (2006) Planning an Ecological Network of Xiamen Island (China) Using Landscape Metrics and Network Analysis. Landscape and Urban Planning, 78, 449-456.

http://dx.doi.org/10.1016/j.landurbplan.2005.12.004

[16] Lindsey, G. (1999) Use of Urban Greenways: Insights from Indianapolis. Landscape and Urban Planning, 45, $145-157$. http://dx.doi.org/10.1016/S0169-2046(99)00023-7

[17] Von Haaren, C. and Reich, M. (2006) The German Way to Greenways and Habitat Networks. Landscape and Urban Planning, 76, 7-22. http://dx.doi.org/10.1016/j.landurbplan.2004.09.041

[18] Hanachi, S. and Ghaznavi, M. (2009) Greenway Planning from Local to Comprehensive Planning of National Multi Objective Routes. Hoviateshahr, 3, 59-70.

[19] Shoaybi, A., Shabani, N. and Oskuie, P.H. (2006) Conservation of Stream Corridors as an Urban Infrastructure Case Study: Evin-Darakeh Stream Corridor. Environmental Sciences, 12, 1-6.

[20] Masnavi, M.R. and Fathi, M. (2011) An Empirical Study to Enhance Sustainable Development of the Urban Highway Landscape and Environmental Conditions Based on Greenway Approach and User's Visual Preferences, the Case of Behesht-e-Zahra and Tondgouyan Highways, Southern Tehran. Armanshahr, 4, 77-89.

[21] Erickson, D. (2004) Connecting Corridors: Implementing Metropolitan Greenway Networks in North America. In: Jongman, R.H.G. and Pungetti, G., Eds., Ecological Networks and Greenways: Concept, Design, Implementation, Cambridge University Press, Cambridge, 200-221. http://dx.doi.org/10.1017/CBO9780511606762.014

[22] Irani BehbahaniI, H. and Berenji, M. (2011) Designing Green Routes to Connect Natural-Historical Inner City. Structures. (Case Study: Shahr-e Rey). Journal of Archaeological Studies, 3, 45-64.

[23] Morris, A.J. (2013) History of Urban Form before the Industrial Revolution. Routledge, London.

[24] Hamidi, M., Habibi, M. and Sabri, R. (1997) Spatial Structure of Tehran. Municipality of Tehran, Tehran.

[25] Harkness, T. and Sinha, A. (2004) Taj Heritage Corridor: Intersections between History and Culture on the Yamuna 
Riverfront (Places/Projects). Places, 16, 62-69.

[26] Moynihan, E.B. (2000) The Moonlight Garden: New Discoveries at the Taj Mahal. Arthur M. Sackler Gallery, Smithsonian Institution and the University of Washington Press, Seattle and London.

[27] Taban, M. and Pashootanizadeh, A. (2010) Index Urban Axis and Ecological River Corridors (Promoting Place Identity Focusing Pedestrian Trails Tourism). Hoviateshahr, 4, 51-62. 